\title{
The Relationship Between Customer Equity \& Its Drivers, Purchase Intentions and Switching Cost. A Study on Traveling Industry in Pakistan
}

\author{
Sohail Akhtar Research (Scholar) \\ Dr. Huma Ali (Assistant Professor) \\ Institute of Banking \& Finance BZU, Multan, Pakistan
}

\begin{abstract}
The key purpose of current research is to investigate the relationship between customer equity, purchase intentions by moderation effect of switching cost. Furthermore this research investigated the relationship between Value Equity, Brand Equity and Relationship Equity toward the customer equity and customers purchase intentions. The data were collected from air passenger at international airport Multan via self administrative questionnaire. The Reliability, KMO, Correlation and Regression analysis used to measure the data. The results indicate that, there is significant relationship between customer equity and purchase intentions, and impact of Value, Brand and Relationship Equity on customer equity and purchase intentions found positive relationship. While Switching Cost also affect the relationship between customer equity and purchase intentions. The present research focuses on services industry there is need to test the model in manufacturing industries for more appropriate results. A study on Traveling Industry in Pakistan relationship between Customer Equity \& its drivers, purchase Intentions and Switching Cost has been not conducted before. In Pakistan traveling industry facing switching cost barrier and current research conducted to fills this gap.
\end{abstract}

Keywords: Customer equity, Value equity, Brand equity, Relationship equity, Purchase intentions Switching cost.

DOI: $10.7176 / \mathrm{EJBM} / 11-4-04$

\section{Introduction}

Airline market has become an important component of the traveling industry in most of the countries. They spend money in a variety of ways (e.g travel, restaurant, hotels, entertainment, and attractions) to sustain the customers. It is critical for every airline to sustain the customers in high competition market. As a result, it will develop into increasingly more important for Airline managers and marketers to identify the variables that support in the attraction and/or protection of different customers (Hutchinson, Lai and Wang, 2009). Thus, the diversity of airlines services and the level of rivalry in the airline industry increase day by day. The customer can switch airlines more easily now as compared to the earlier period. Airlines that adopt changes slowly certainly suffer the losses. In such circumstances, having solid customer equity strategies are becoming more and more important. Apart from this study, customer equity research in the airline industry is surprisingly understudied. Thus, the customer equity is currently extensively used to determine total life time value of a customer. To facilitate companies and focuses on their marketing struggles and make safe customers, enhancing upcoming profit theory of customer equity is an emerged instrument (Lee et all., 2014). In such a dynamic, active, and imperative market, the firms require to be familiar with how to maintain, grow, and expand their belongings specially customer equity. Therefore the study is devoted into the customer equity and its constructs (Lee et al., 2007; Kim and Ko, 2012; Rust, Zhang, Ko and Lee, 2013;Kim and Ko, 2005).

Understanding and managing the worth of Airline passengers is distinctive and comprehensive. Specifically, it is imperative for Airline marketers to know, which equity can rely on increasing customer behavioral intentions through specific customer equity drivers. In order to address this question, we use Rust, Zeithaml, and Lemon"s (2000); Wang (2014) Kim, Ko. Xu and Hang (2012); Kim and Ko (2012); theoretical structure of customer equity that includes three vital fundamentals: brand, value, and relationship equity. The brand equity is one of the most familiar customer equity drivers; this construct capture consumers" psychological connection to Air passenger (Wang, 2014; Chen and Chang, 2008). Brand equity creates various advantages, which brand equity allows the industries to charge a higher price for products/services; to increase gross margin; provides authority with customers; increase the customers; serves as weapon against customers switching due to unique product and services. Relationship equity is one of the main issues presently being addressed by marketing practitioners and scholastic researchers (Low \& Johnston, 2006). Industries that have victorious relationships with preferred customers in turn obtain the advantages of higher profitability through decreased marketing and managerial cost. Therefore, the industries progressively more urged to create customer relationships that expand beyond individual market connections. And third is, value equity is usually defined as the consumers" objective assessments of the utilization of a product based on their perceptions of how much paid (like, time, efforts, and money) for what is received (like, worth, benefits and quality). There are three components of value equity; 
quality, price and convenience of the products/services. In airline setting, quality and price are purpose attributes that can contribute to succeed airline products services. With the increase of competition in airline industry by unique products and services, it has become highly necessary to analyze the effect of equity toward purchase intentions. High purchase intentions resulting will increases industry overall performance. Most of the previous studies measured the effects of brand equity towards brand preference and purchase intentions (Chen and Chang, 2008). Now in dynamic and highly competitive environment, the single strategy (brand equity) is not enough to sustain the customers. The era is needed to explore an additional strategy to increase overall performance in airline setting. Based on the above discussion, the present study conducted to fill this gap through customer equity and its drivers. Providing special customers services is most essential for developing long time relationship with customers and gaining favorable customer image. Thus, the relationship, value and brand equity are vital construct of customer equity to increase the customer value. The present study examine that how customer equity relates to purchase intentions and customers purchase behavior in a airline services setting toward the purchase intentions.

\section{Literature review: \\ 2.1 Customer Equity}

Customer equity is generally defined as the discounted total of consumer's life time value that has been considered the most determinant of long term value of the company (Hyun, 2009; Lee et al., 2014; Yoshida \& Gordon, 2012). The definition of customer equity first defined as by the Dieghton and Blattbergg "Overall life time value of the current and potential customer". Further Kim \& Ko, (2012) defined customer equity as, the overall profit consumers might give over the time of association with company rather than value of a consumers takes to a company is limited to the from each and every transaction. According to Lemon et all., (2001); Vogel et all., (2008); Kim et all, (2010) three types brand, value and relationship equity as vital constructs of customer equity. The thought of consumer value has newly been in the awareness because of the ideas that consumer value is extremely linked to a company's shareholder equity and company performance (Hyun, 2009). For example, Hyun (2009) found positive and constructive associations among consumer equity plus a company equity and argued four diverse approaches for analyzing company customer equity through two dimensions: (1st) unit analysis (2nd ) time prospective, some ways are calculating customer equity: the use of past value or expected upcoming value. Past value measure of a great extent the consumers have been value to firms to in the earlier period. In other way, expected future value is the analysis of how much customers will be worth to the firms in future. In contrast, measurement concern the component of analysis in which companies compute customer equity based on any single. In contrast, projected future value is the measure of how many customers will be worth to the company in the future. Another dimension of measurement concerns the unit of analysis in which organizations calculate customer equity based on either individual basis or mentioned group or particular group of customers. Numerous way of dealing analyzed customer equity by utilizing diverse method.

The idea of customer equity is a supportive instrument by both a mathematical and theoretical (Yoshida \& Gordon, 2012; Chang and Chen, 2007;Rust et al.,2000). The statistical models utilize to evaluate marketing efficiency throughout a measure of gain on investment in marketing activities. Many of the previous studies measure the customer equity empirically. Rust et al.,(2004) analyzed customer's past and present value base on buying of the selected brand and future intentions. And other studies focused on the purchase intentions at a particular point of view, but they accounted low attitude with products, services and expected performance (Yoon and Oh 2016).

\subsection{Determinant of Customer Equity: \\ 2.2.1 Value Equity}

Value equity (VE) is the consumers evaluation based on the price, convenience. Further Hyun, (2009); Yoshida \& Gordon, 2012; Vogal, evanschitzky and Ramaseshan 2008) defined value equity as the construct of customer equity which indicates that what customer received (products or services) against that is paid. Thus, favorable prices show strong value equity and high prices show relatively low value equity (VE). In other way, value equity theory believe that equity generate significant affect state that lead to optimistic attitude, such as high brand preference \& purchase intention. The Lee et al,. (2014) suggested that business value equity; customers asses products for their credibility, marketability \& value. Value equity (VE) reproduces comparatively objective customers $^{\text {ee }}$ thoughts toward products or services and is regarded as unilateral equity based on a company products or services competency. Companies can enhance value via giving value beyond customers ${ }^{\text {ee }}$ probability or via decreasing customers provided incentives (Wood, 2012). According to Yoshida \& Gordon, (2012); Kim \& Ko (2011). Value equity is the impartial evaluation of uses of a brand based on the observation of what is acknowledged and what is given up. There are three key influences on value equity which are quality, price and availability. Vogal, Evanschitzky \& Ramaseshan, (2008) suggested that value equity theory creates balance and show positive effect which lead to positive attitude like satisfaction and loyalty which lead to high customer 
purchase intentions. Zhang, Doorn, Leeflang, (2014); Kim et all,. (2012); Hyun,(2009); Vogel et al., (2008) Studied the customer equity and its constructs in different context like hospitality, cellular industry, banking and beverage industry.

\subsubsection{Relationship Equity}

Relationship equity indicates the tendency of consumers ${ }^{\text {ee }}$ to keep on an association with particular brands, because they have received preferential treatment and additional incentive. Usually, loyalty programs are additional incentives the companies manage may increase relationship. Relationship equity is the most important driver of customer equity to analyzing consumer perception regarding firm's products and services. When companies give importance customer recognitions then customer perceived high relationship with companies like affinity program, community building program, loyalty program effort to build relationship equity (Sun et al., 2016). According to Kim and Ko (2012) Loyalty programs are most important tool to enhance the relationship equity. Thus, the companies required to connect in many loyalty establishing actions like as attraction program (affinity), specific behavior program and society establishing programs. To compete in airline industry setting, the loyalty reward should award with consumers financial rewards for buy to make sure continuous support. Affinity program represent the consumers think some psychosomatic losses when he decide to patronizing an airlines which give him a sense of self individuality. Society building program is likely to affinity establishing program in that it create to enhance the psychosomatic cost of not break off the association during reinforcing the connection the between customers \& airlines. And the last one, particular achievement program most important representative of the psychosomatic incentive to target consumers which are indifferent about the monitory incentives. According to Yoon and Oh (2016); Yoshida \& Gordon (2012); Kim \& Ko (2011) the relationship equity capacity for a customers to carryon relationship via brand that go beyond subjective or objective evaluation of brand. Normally talking, a high relation with consumers a most important asset from effectiveness point of view. The cost of this firm will be lower to sustain existing customers than create to newest customers. When customers choose a company then relationship equity will be start. The first buying knowledge, when significantly perceived, normally leads to rebuy, and so the company can enhance its relationship equity by utilizing numerous loyalty programs and action. According to Kim et al., (2012) relationship equity (RE) refer to an option completed by customers until they support a brand on the relationship they believe to the company performance will be increase. Thus, the relationship equity have play significant role to increase organization performance through greater customers purchase intentions. The brands have greater relationship equity in every category provided positively higher purchase intentions (Low and Johnston, 2006).

\subsubsection{Brand Equity}

The brand equity have prime role in field of marketing research. It has various benefits for business man like successful brand extension and successful product, high acceptance of promotional strategy, strong entry barrier to competitor, higher level of satisfaction and loyalty (Hanaysha, 2016). The modern theories of marketing and practices acknowledge brand equity (BE) as a key trade tactical asset of firm. Vukasovic, (2016) suggested that brand show influences at three basic market sections: Financial, products and services, value collected from these market suggested as brand equity. The Brand Equity is the essential idea of the marketing. However, the comprehensive has been taken on the brand equity; a detail on this topic is highly fragmented and inconclusive. Various descriptions have been explained by different authors, most of them from a consumer prospective. So base on this information the brand equity power depend upon the mind of consumer. And other from the financial approaching brand equity (BE) defines as the monitory values of a brand to the firm. Vukasovic, (2016) defined that monetary values are final outcomes from customer to a brand. Most of the previous research focused on the customer based brand equity. Keller and Aker develop foundation for customer base brand equity. According to Vukasovic, (2016); Sharma and Patel, (2015); Wash, Burn and plank, (2015) the brand equity is the set of assets and liabilities that are linked to a brand. And these assets are brand relationship; brand perceived value, brand knowledge and other proprietary asset. Washburn and Plank, (2015) further suggested that a brand liabilities asset provide to it equity, which may differ depending upon context, and it can be grouped into five categories. Sun et all. (2016) suggested that brand equity perform three roles. First is that to encourage consumer through brand recognition or perception. And second is that, brand equity customer is drawn frequently through well known and favored brand. Third brand equity, consumers form affecting bond with company's by their attachments to brand (Lemon et al., 2001). Brand equity is a sum of characteristic that is unique to a brand. Brand equity is the perception about the product and services which are provided to a brand. Brand equity has several benefits. It is allows an organizations to charge higher prices (Hanaysha, 2016). Company use brand equity as source of power channel to deal with customers. Brand equity such a value linked through brand to happen when customer similar to it (Yoon and oh 2016). Brand equity is an essential marketing asset which can produce a distinctive and friendly association between company and its stakeholder and long term purchasing behavior (Wang, 2014). To add up, the brand equity is usually believed to be an essential provider to customers purchase intentions. Apart from this study brand equity study in airline industry surprisingly understudied 
(Cheng and Chang 2008; Wang 2014;Kim and Kim, 2004). The increasing importance in these topics, customer equity, and its three construct the relationship with intention to purchase from customer prospective need to measure more significant relationship. According to Chen and Chang (2008) and Wang (2014) brand equity has positive influence on consumer purchase intentions, and ultimately brand choice. Furthermore, the strong brand equity brings positive effect toward the product and services as well as in customer purchase intentions (Emore and Pangemanan 2015).

\subsection{Purchase intention}

Purchase intention is define as behavioral intention which an intellectual state is reflecting a person object to connect in some action contained by particular time period. Thus, purchase intention assumed to be instant antecedent of behavior. High customer equity has positive effect on the products and services which lead to high purchase intention. Purchase intention a brand position on how well the equity increase and sustained. If the purchase intention will be improved, the customers build loyalty and trust which lead to stay on buying a specific brand (Hanaysha, 2016). Customer equity and it driver has greater impact on the purchase intention. According to Cheng and Chang (2008) the brand equity significance influence customer brand preference \& purchase intentions and ultimately brand preference. The present study examines that how customer equity relates to customer switching behavior in airline services setting. These settings are usually typified by the customers, high switching costs, and complete period. Viewed in this approach, equity goes beyond the basic philosophy of customer achievement and value. Equity furthermore stresses advantages that are balanced to one's inputs into the relationship.

\subsection{Switching Cost}

The measuring of moderating variable support the airlines marketers to recognize who is expected to be more or less impacted from the managing of the customer equity drivers toward the airline industry. Previous studies have suggested that switching cost moderate effects toward the brand equity, brand preference and intentions to repurchase (Chen and Chang 2008; Low and Johnston 2006). Thus, analyzing switching behavior is not complex. This is because at any time in a current customer relationship, it is practicable to ask customers about their future interest in switching to another airline. While their responses are basically indications of interests and are not guarantee. According to Low \& Johnston, (2005) switching cost have two important benefits. First, the study can take into custody this information. This then makes it comparatively straightforward to link switching behavior and customer equity driver for investigative purposes. Second, the attention to switch is a logically well-built indicator of expectations, valid buying behavior mostly when the customers have the substitute of switching airlines.

\section{Theoretical Framework \& Hypothesis:}

\subsection{Research Model:}

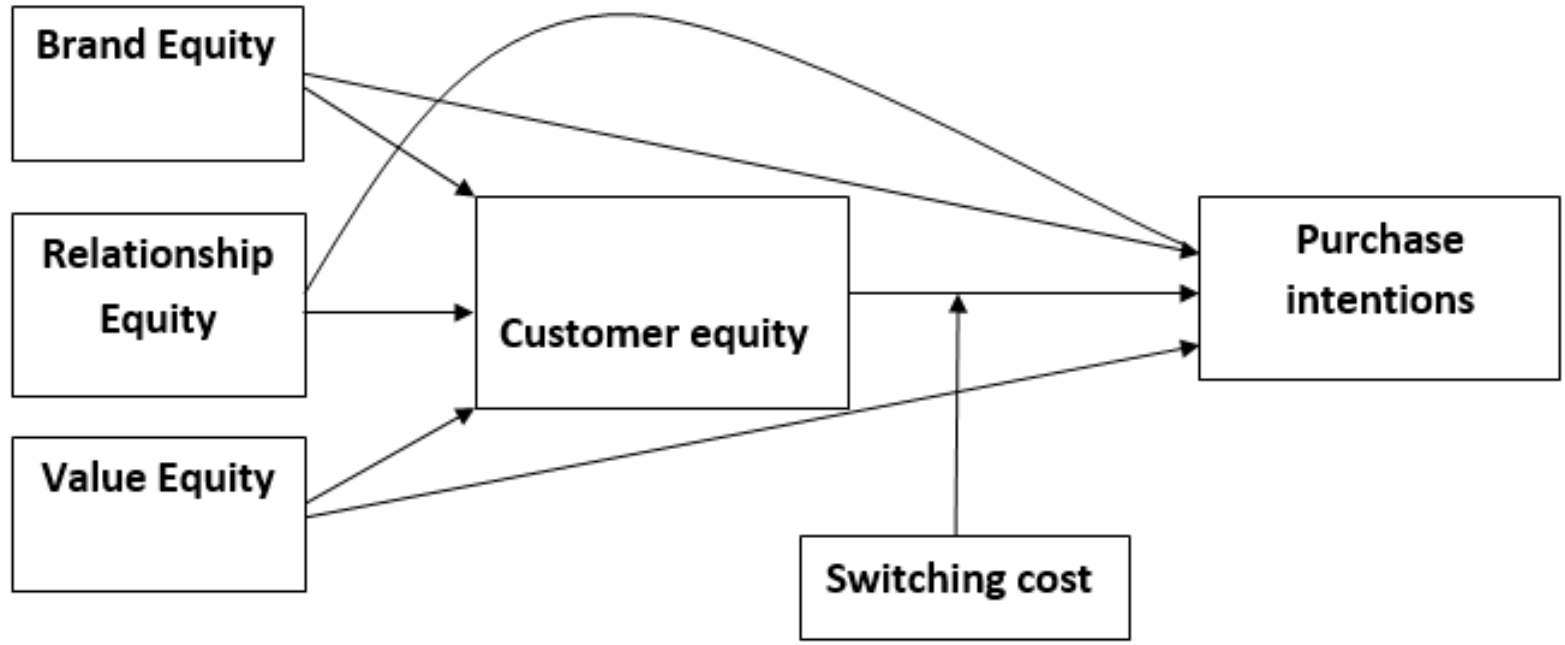

Figure1. Conceptual Framework

\subsection{Hypothesized Research Model:}

This part is about hypothesized research model explaining how relationships are developed. 


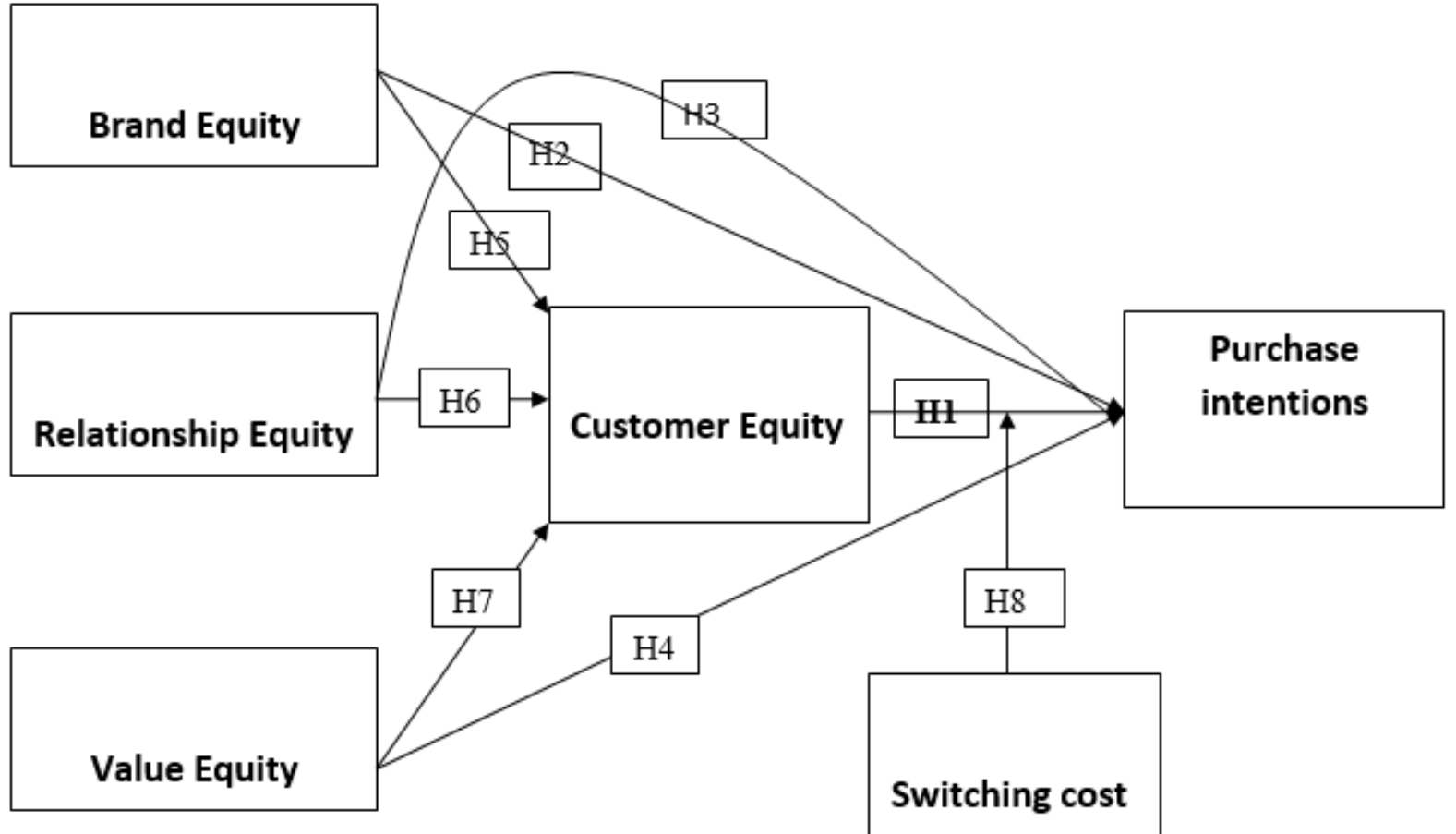

Figure.2 Hypothetical Research Model

\subsection{Research Hypothesis}

H1: Customer equity has significant impact on the purchase intentions.

H2: Brand equity has significant impact on the purchase intentions.

H3: Relationship equity has significant impact on the purchase intentions.

H4: Value equity has significant impact on the purchase intentions.

H5: Brand equity has significant impact on the customer equity.

H6: Relationship equity has significant impact on the customer equity.

H7: Value equity has significant impact on the customer equity.

H8: The greater level of switching cost, greater probability will exist that customer equity will lead to customers higher intentions to purchase.

\section{Research design}

\subsection{Sampling Description \& Population}

The required data is gathered from the airline industry. The most especially data is gathered from the airline passengers as of Southern Punjab of (Multan) Pakistan. Mostly respondent are belong to Southern Punjab. The research is done in the airline customers of Punjab (Multan) in which basic information are provided to the Airline customers concerning the purpose of the research. The study also describe that how to give feedback or to fill up the questionnaire in a way to have reliable \& valid feedback. The typical conditions were explained to the passengers for their easiness.

\subsection{Techniques of data collection}

To collecting the data questionnaire has been developed. The scale has been adopted from the past studies. To collect the accurate information five point likert scale is used. All the questions are ranging from 1 to 5 , where one is decoding as strongly disagree and 5 decoded as strongly agree. The data is gathered from the all airline passenger \& convenient sampling technique is used in this research a file of consumers cannot be generated. To attain necessary information and to obtain answers of research questions, 330 questionnaires were distributed amongst different airline passengers. Out of 330 questionnaires only 314 were returned. Out of 314,14 were not completed filled. So, only 294 questionnaires were available for analysis purpose. The response was $90 \%$.

\subsection{Variables:}

\subsubsection{Customer equity and its drivers}

Customer equity constructs contain 17-items. Brand equity contain 5-items which are developed by Akker (1991);Yoo and Danthu (1997); Yoo, Danthu and Lee (2000). Likert scale is used to gathered feedback of all items which is ranging from one to five. There is 1 is taken as Strongly Disagree \& 5 taking as Strongly Agree. 
Value equity is analyzed through 7-items scale, adopted from Rust et,. all (2004);Parasuraman et al. (1988) Brady et all,. (2002). Likert scale is used to gathered feedback of all items which is ranging from one to five. There is 1 is taking as Strongly Disagree \& 5 taken as Strongly Agree.

Relationship equity contains 5-items. Which are developed by Bugel, Verhoef,and Buunk (2011) and Gwinner et al.(1998), Baek(2009). Likert scale is used to gathered feedback of all items which is ranging from one to five. There is 1 is taken as Strongly Disagree \& 5 taking as Strongly Agree.

\subsubsection{Purchase intentions}

Purchase intention is measured by 3-items scale, developed by Jamal and Goode (2001), and Chen and Chang (2008). Likert scale is used to gathered feedback of all items which is ranging from one to five. There is 1 is taken as Strongly Disagree \& 5 taking as Strongly Agree.

\subsubsection{Switching cost}

Moderating variable switching cost is measured through 3-items scale, adopted from Jones et al., 2000. The responses of all items have been collected using Likert scale which is ranging from 1 to 5 , where 1 coded as Strongly Disagree and 5 coded as Strongly Agree.

\subsection{Data analysis Method:}

To find the results SPSS software is used in this research. Primarily the data is arranged, coded and put into the SPSS. Different statistical techniques are used to measure like as demographic analysis, missing value, reliability, validity and regression analysis also measured through SPSS.

\section{Analysis and findings:}

\subsection{Demographic Analysis}

Demographic variables that are used are gender, age, education, and experience with airlines services using and duration of using services. Gender Analysis out of 294 participants, 95.2\% participants were male while 14\% were female respondents. Age of the respondents; that indicates $8.8 \%$ respondents are 26 or less years which shows small group of sample. In other way $60.9 \%$ respondents belong to $21-30$ years which show that majority respondents are young. $24.5 \%$ lie in age range of 31-40 years. While only $4.4 \%$ belong to range of $41-50$ years. Lowest portion was of people age range of 51-60 years which is only $1.4 \%$ of total sample. The percentage of education of participants was $27.2 \%$ i.e 80 respondents were graduated and $47.6 \%$ i.e 140 was postgraduate. $20.4 \%$ i.e 60 respondents were having M.phil degree and only 14 making up $4.3 \%$ of total sample were having $\mathrm{Ph} . \mathrm{D}$ degree. Figure 5.3 indicates the graphical frequency analysis of participants with respect to education of respondents. The 166 respondents were availing services from $0-5$ years making up $56.5 \%$ of total sample. 82 were having experience of 6-10 years, 27 were having 11-15 years. 27 were having 11-5 years, 10 were having experience of 10-20 years, while the only 9 respondents were having experience of 21 years.

\subsection{Reliability analysis:}

Reliability is of assessing the quality of the scale process used to collect the data in research, in order for the consequences from a study to be considered valid; the measurement process must first be consistent. The results of this research are Brand equity is 0.869 , Vale equity 0.875 , Relationship equity 0.840 . Purchase intentions 0.836 and switching cost is 0.714 .

\subsection{KMO and Bartlett Test:}

The KMO and Bartlett's examination is taken up to study the sufficiency of the sample selected for the study. If the significance value of this test is greater than 0.5 and significance level is less than 0.05 in this situation results are satisfactory. For a time KMO and Bartlett test value sphericity reveal "between" 0.5 to 0.7 . In this research $\mathrm{KMO}$ and Bartlett test value is 0.961 that is greater than 0.5 and significance level is 0.000 that is excellent for study. The results of the study prove that the data is meaningful for next analysis.

\subsection{Correlation Matrix}

Correlation matrix indicates the relationship of variable i.e customer equity, brand equity, value equity, relationship equity, purchase intention and switching cost. Below table show that all variable significantly correlate with each other. The customer equity has significant correlation with purchase intention $\mathrm{r}=(0.752, \mathrm{p}<$ $0.1)$, brand equity with purchase intentions $\mathrm{r}=(0.669, \mathrm{p}<0.1)$, relationship equity with purchase intentions $\mathrm{r}$ $=(0.737, \mathrm{p}<0.1)$, value equity with purchase intentions $\mathrm{r}=(0.715, \mathrm{p}<0.1)$, brand, relationship and value equity with customer equity have positive correlation, $\mathrm{r}=(0.943, \mathrm{p}<0.1), \mathrm{r}=(0.831, \mathrm{p}<0.1), \mathrm{r}=(0.9 .47, \mathrm{p}<0.1)$. 
Table.1 Mean, Standard deviation \& correlation analysis of constructs.

\begin{tabular}{|l|l|r|r|l|l|l|l|l|l|}
\hline & Variables & Mean & S.D & CE & BE & RE & VE & PI & SC \\
\hline 1 & Customer equity & 8.0664 & 1.61944 & 1 & & & & & \\
\hline 2 & Brand equity & 3.3823 & .75321 & $.943 * *$ & 1 & & & & \\
\hline 3 & Relationship equity & 3.5048 & .73427 & $.831 * *$ & $.720 * *$ & 1 & & & \\
\hline 4 & Value equity & 3.5159 & .74506 & $.947 * *$ & $.803 * *$ & $.751 * *$ & 1 & & \\
\hline 5 & Purchase intention & 3.4773 & .81327 & $.752 * *$ & $.669 * *$ & $.737 * *$ & $.715 * *$ & 1 & \\
\hline 6 & Switching cost & 3.2404 & 1.07213 & $.592 * *$ & $.528 * *$ & $.568 * *$ & $.568 * *$ & $.583 * *$ & 1 \\
\hline
\end{tabular}

*.Correlation is significant at the 0.05 level (2-tailed).

**.Correlation is significant at the 0.01 level (2-tailed).

\subsection{Regression Analyses}

To forecast results of dependent variable by taking one or more independent variables the researchers are use regression analysis technique. Given below equation show the regression analysis from

$$
\mathrm{Y}=\mathrm{Bo}+\mathrm{B} 1 \mathrm{X} 1+\mathrm{B} 2 \mathrm{X} 2+\ldots \ldots \ldots+€
$$

In this equations $\mathrm{X} 1, \mathrm{X} 2, \ldots \ldots \ldots$... and so on taken as independent variable to predict the results of $\mathrm{Y}$ labeled as dependent variable whereas B1, B2.......... and so on are the multiplier that reveal the significant relationship of independent variable towards the dependent variable and here is $€$ value and $\mathrm{Y}$ is forecasted to have when all independent variable are equal to zero.

Table 5.2 Regression Analysis of customer equity toward purchase intentions

H1

Table no.2 Regression analysis of customer equity $\&$ purchase intentions

\begin{tabular}{|c|c|c|c|c|c|c|c|c|c|}
\hline \multirow[b]{2}{*}{ Model } & \multicolumn{2}{|c|}{$\begin{array}{c}\text { Un-standardized } \\
\text { Coefficients }\end{array}$} & \multirow{2}{*}{$\begin{array}{c}\begin{array}{c}\text { Standardized } \\
\text { Coefficients }\end{array} \\
\text { Beta }\end{array}$} & \multirow[b]{2}{*}{$\mathbf{t}$} & \multirow[b]{2}{*}{ Sig. } & \multicolumn{2}{|c|}{$\begin{array}{c}\text { Model } \\
\text { Summary }\end{array}$} & \multicolumn{2}{|c|}{ ANOVA } \\
\hline & B & Std. Error & & & & $\mathbf{R}^{2}$ & Adj. $\mathbf{R}^{2}$ & $\mathbf{F}$ & Sig. \\
\hline $\begin{array}{l}1 \text { (Constant) } \\
\text { Customer }\end{array}$ & 0.432 & 0.159 & & 2.710 & .000 & 0.565 & 0.564 & 379.473 & .000 \\
\hline Equity & 0.378 & 0.019 & .752 & 19.480 & .000 & & & & \\
\hline
\end{tabular}

Dependent Variable: Purchase Intentions

To test the hypothesis the regression analysis has been performed. H1 is measured the impact of customer equity on purchase intentions. The finding indicates that there is significant relationship between customer equity \& purchase intentions. $\mathrm{R}^{2}$ value is .565 which shows that $56.9 \%$ variation in (IV) purchase intentions is due to (DV) customer equity. F-test is the fitness value of the model which is highly significant with significant value .000 . Beta value 0.725 indicates the one percent changes in independent variable customer equity bring the change in dependent variable (PI) $72.5 \%$ whereas significance level is .000 .

Table no.3 Regression Analysis of brand equity toward purchase intentions

\begin{tabular}{|c|c|c|c|c|c|c|c|c|c|}
\hline \multirow[b]{2}{*}{ Model } & \multicolumn{2}{|c|}{$\begin{array}{c}\text { Un-standardized } \\
\text { Coefficients }\end{array}$} & \multirow{2}{*}{$\begin{array}{c}\begin{array}{c}\text { Standardized } \\
\text { Coefficients }\end{array} \\
\text { Beta } \\
\end{array}$} & \multirow[b]{2}{*}{$\mathbf{T}$} & \multirow[b]{2}{*}{ Sig. } & \multicolumn{2}{|c|}{$\begin{array}{c}\text { Model } \\
\text { Summary }\end{array}$} & \multicolumn{2}{|c|}{ ANOVA } \\
\hline & B & Std. Error & & & & $\mathbf{R}^{2}$ & Adj. R $^{2}$ & $\mathbf{F}$ & Sig. \\
\hline 1 (Constant) & 1.033 & .163 & & 6.349 & .000 & 0.448 & 0.446 & 237.102 & .000 \\
\hline $\begin{array}{l}\text { Brand } \\
\text { Equity }\end{array}$ & .723 & .047 & .669 & 15.398 & .000 & & & & \\
\hline
\end{tabular}

Dependent Variable: Purchase Intentions

Hypothesis $\mathbf{H 2}$ is executed by regression analysis. Where the brand equity has significant relationship toward the purchase intentions. $\beta$ value 0.669 show that $(\beta=0.669, p<0.01)$ brand equity has $66.9 \%$ causing in purchase intentions. $\mathrm{R}^{2}$ values indicate that 0.448 there is $44.8 \%$ variation in the relationship between brand equity \& purchase intentions. 
H3

Table no. 4 Regression Analysis of relationship equity toward purchase intentions

\begin{tabular}{|c|c|c|c|c|c|c|c|c|c|}
\hline \multirow[b]{2}{*}{ Model } & \multicolumn{2}{|c|}{$\begin{array}{c}\text { Un-standardized } \\
\text { Coefficients }\end{array}$} & \multirow{2}{*}{$\begin{array}{c}\begin{array}{c}\text { Standardized } \\
\text { Coefficients }\end{array} \\
\text { Beta } \\
\end{array}$} & \multirow[b]{2}{*}{ T value } & \multirow[b]{2}{*}{ Sig. } & \multicolumn{2}{|c|}{$\begin{array}{c}\text { Model } \\
\text { Summary } \\
\end{array}$} & \multicolumn{2}{|c|}{ ANOVA } \\
\hline & B & Std. Error & & & & $\mathbf{R}^{2}$ & Adj. $\mathbf{R}^{2}$ & $\mathbf{F}$ & Sig. \\
\hline 1 (Constant) & .615 & .157 & & 3.921 & .000 & 0.544 & 0.542 & 348.125 & .000 \\
\hline $\begin{array}{l}\text { Relationship } \\
\text { Equity }\end{array}$ & .817 & .044 & .737 & 18.658 & .000 & & & & \\
\hline
\end{tabular}

Dependent Variable: Purchase Intentions

Table 4 Regression Analysis of relationship equity toward purchase intentions

Regression analyses of $\mathrm{H} 3$ relationship toward the purchase intentions have been performed. $\mathrm{R}^{2}$ value is 0.544 which shows that $54.4 \%$ variation in purchase intentions due to relationship equity. F-test is the fitness value of the model which is highly significant with significant value .000 it's also indicates good value for data. Beta value $(r=0.737, p<0.01)$ indicates the one percent change in independent variable relationship equity bring the change in dependent variable purchase intention $73.7 \%$ whereas significance level is .000 .

H4

Table no.5 Regression Analysis of value equity toward purchase intentions

\begin{tabular}{|c|c|c|c|c|c|c|c|c|c|}
\hline \multirow[b]{2}{*}{ Model } & \multicolumn{2}{|c|}{$\begin{array}{c}\text { Un-standardized } \\
\text { Coefficients }\end{array}$} & \multirow{2}{*}{$\begin{array}{c}\begin{array}{c}\text { Standardized } \\
\text { Coefficients }\end{array} \\
\text { Beta }\end{array}$} & \multirow[b]{2}{*}{$\mathrm{t}$} & \multirow[b]{2}{*}{ Sig. } & \multicolumn{2}{|c|}{$\begin{array}{c}\text { Model } \\
\text { Summary }\end{array}$} & \multicolumn{2}{|c|}{ ANOVA } \\
\hline & B & Std. Error & & & & $\mathbf{R}^{2}$ & Adj. $R^{2}$ & $\mathbf{F}$ & Sig. \\
\hline 1 (Constant) & .733 & .160 & & 4.569 & .000 & 0.511 & 0.510 & 305.399 & .000 \\
\hline Value Equity & .780 & .045 & .715 & 17.476 & .000 & & & & \\
\hline
\end{tabular}

Dependent Variable: Purchase Intentions

Table 5 Regression Analysis of value equity toward purchase intentions

H4 is performed through regression analysis of relationship equity on purchase intentions. Relationship equity has positive impact on the purchase intentions. The results are, beta values $(\beta=0.715, \mathrm{p}<0.01)$ shows that value equity positively causing $71.5 \%$ toward purchase intentions, $\mathrm{R}^{2}$ values indicate that $51.1 \%$ variance in relationship D.V and I.V which shows in table 5.

H5

Table no.6 Regression Analysis of brand equity toward customer equity

\begin{tabular}{|c|c|c|c|c|c|c|c|c|c|}
\hline \multirow[b]{2}{*}{ Model } & \multicolumn{2}{|c|}{$\begin{array}{l}\text { Un-standardized } \\
\text { Coefficients }\end{array}$} & \multirow{2}{*}{$\begin{array}{c}\text { Standardized } \\
\text { Coefficients } \\
\text { Beta }\end{array}$} & \multirow[b]{2}{*}{ T value } & \multirow[b]{2}{*}{ Sig. } & \multicolumn{2}{|c|}{$\begin{array}{c}\text { Model } \\
\text { Summary }\end{array}$} & \multicolumn{2}{|c|}{ ANOVA } \\
\hline & B & Std. Error & & & & $\mathbf{R}^{2}$ & $\begin{array}{l}\text { Adj. } \\
\mathbf{R}^{2}\end{array}$ & $\mathbf{F}$ & Sig. \\
\hline 1 (Constant) & 1.207 & .145 & & 8.336 & .000 & 0.890 & 0.889 & 2353.6690 & .000 \\
\hline $\begin{array}{l}\text { Relationship } \\
\text { Equity }\end{array}$ & 2.028 & .042 & .943 & 48.515 & .000 & & & & \\
\hline
\end{tabular}

Dependent Variable: customer equity

In the relationship of brand equity toward customer equity regression analysis has been carry out. The brand equity bring $94.3 \%$ change on customer equity which is highly significant $(\beta=0.943, p<0.01)$. In model summary $\mathrm{R}^{2}$ values 0.890 indicates that $89 \%$ variance in the relationship of brand equity \& customer equity which is shows in table 6 .

H6

Table no.7 Regression Analysis of relationship equity toward customer equity

\begin{tabular}{|c|c|c|c|c|c|c|c|c|c|}
\hline \multirow[b]{2}{*}{ Model } & \multicolumn{2}{|c|}{$\begin{array}{l}\text { Un-standardized } \\
\text { Coefficients }\end{array}$} & \multirow{2}{*}{$\begin{array}{c}\begin{array}{c}\text { Standardized } \\
\text { Coefficients }\end{array} \\
\text { Beta } \\
\end{array}$} & \multirow[b]{2}{*}{ T value } & \multirow[b]{2}{*}{ Sig. } & \multicolumn{2}{|c|}{$\begin{array}{c}\text { Model } \\
\text { Summary }\end{array}$} & \multicolumn{2}{|c|}{ ANOVA } \\
\hline & B & Std. Error & & & & $\mathbf{R}^{2}$ & $\begin{array}{l}\text { Adj. } \\
\mathbf{R}^{2}\end{array}$ & $\mathbf{F}$ & Sig. \\
\hline 1 (Constant) & 1.639 & .257 & & 6.385 & .000 & 0.691 & 0.690 & 654.135 & .000 \\
\hline $\begin{array}{l}\text { Relationship } \\
\text { Equity }\end{array}$ & 1.834 & .072 & .831 & 25.576 & .000 & & & & \\
\hline
\end{tabular}

Dependent Variable: customer equity 
In this relationship $\mathrm{R}^{2}$ value is 0.691 which shows that $69.1 \%$ variation in purchase intentions due to relationship equity. Beta value 0.831 indicates the one percent change in independent variable relationship equity bring the change in dependent variable purchase intention $83.1 \%$ whereas significance level is .000 which is indicated in table 7 .

H7

Table no.8 Regression Analysis of value equity toward customer equity

\begin{tabular}{|c|c|c|c|c|c|c|c|c|c|}
\hline \multirow[b]{2}{*}{ Model } & \multicolumn{2}{|c|}{$\begin{array}{c}\text { Un-standardized } \\
\text { Coefficients } \\
\end{array}$} & \multirow{2}{*}{$\begin{array}{c}\begin{array}{c}\text { Standardized } \\
\text { Coefficients }\end{array} \\
\text { Beta } \\
\end{array}$} & \multirow[b]{2}{*}{ T value } & \multirow[b]{2}{*}{ Sig. } & \multicolumn{2}{|c|}{$\begin{array}{c}\text { Model } \\
\text { Summary }\end{array}$} & \multicolumn{2}{|c|}{ ANOVA } \\
\hline & B & Std. Error & & & & $\mathbf{R}^{2}$ & $\begin{array}{l}\text { Adj. } \\
\mathbf{R}^{2}\end{array}$ & $\mathbf{F}$ & Sig. \\
\hline $1 \quad$ (Constant) & .830 & .147 & & 5.649 & .000 & 0.897 & 0.896 & 2532.580 & .000 \\
\hline $\begin{array}{l}\text { Relationship } \\
\text { Equity }\end{array}$ & 2.058 & .041 & .947 & 50.325 & .000 & & & & \\
\hline
\end{tabular}

Dependent Variable: customer equity

By performing the regression analysis of value equity toward the customer equity, the value equity brings the positive $94.7 \%$ change in customer equity $(\beta=0.943, \mathrm{p}<0.01)$. Variance in the relationship of value equity $\&$ customer equity is $89.7 \%$ which is shows in table 8 .

\subsection{Moderation analysis:}

To examine the moderation of switching cost between customer equity and purchase intentions

Moderation is the procedure describes how linkage among two variables influenced through the third variable named as moderator. Interaction is definite term used for moderator, checking the moderating variable can either increase the power of relationships or decrease it in opposite way.

H8

Table no.9.The moderation of switching cost between customer equity and purchase intentions.

\begin{tabular}{|l|l|l|l|}
\hline \multicolumn{1}{|c|}{ Variables } & \multicolumn{1}{|c|}{$\mathbf{R}^{\mathbf{2}} \Delta \mathbf{F}$} & \multicolumn{1}{c|}{ B } \\
\hline Customer equity & 0.656 & $556.889^{000}$ & $0.682^{000}$ \\
Purchase intentions & 0.675 & $301.879^{000}$ & $0.123^{000}$ \\
Interaction & 0.675 & $200.623^{000}$ & $0.066^{000}$ \\
\hline
\end{tabular}

Table .9 Moderation Analysis of Switching Cost

Table 9 shows that the impact of customer equity toward the purchase intentions by moderating analysis of switching cost is significant by the value of $b 1>0$. In this condition the switching cost moderate as enhancer. If the $b 1>0 . b 3>0$ indicates the relationship exist between the variable.

\section{Conclusion}

The current study examines that how customer equity and its drivers affected the brand purchase intentions by moderation taking into consideration role of switching cost. Further driver of customer equity significantly affect the customer equity. Literature Review explains the background of all variables which are customer equity and its constructs, purchase intentions and switching cost defined as a moderator. After that association between customer equity, purchase intention on the basis of past studies.

According to Hayun, (2009) drivers of customer equity value, brand and relationship equity have strengthened the customer equity. And customer equity effect customers purchase intentions (Kim and Ko, 2102) Thus, present research included that customer equity drivers would increase the customer equity and purchase intentions this relationship enhanced by switching cost as a moderator by the regression analysis of customers equity. Which encourage the results to reduce probability and strengthen relationship with airlines which lead to customers purchase intentions. This indicates that in services proving industry specially airlines industry customer equity key construct because of its impact on intentions to purchase. So the customer equity purchase intentions lead to the development of long time relationship. In addition to recognized the significance of customer equity on airline profitability.

The researcher proved that the relationship between customer equity, customer purchase intentions, measuring beta value is .752 with the significance level is .000 . Therefore, the results indicates that there is significance relationship exist between customer equity, customer purchase intentions. The results of this study are accordance with past researches (Huchinson et al.,2009; Yoon and Oh 2015; Rust et al., 2004).

The relationship between customer equity constructs which is brand equity, relationship equity and value equity toward the purchase intentions proved that there is positive relationship between them. The beta values of , relationship between customer equity constructs which are brand equity, value equity and relationship equity toward the purchase intentions beta values are $.669, .715$ and .737 on this relations significance level was 
also .000 with reference of (Vogel et al., 2008); (Wang, 2014); (Chen and Chang, 2008); (Low \& Johnston, 2006). After that the moderation effect of switching cost is analyzed. The beta value .682 shows that the relationship exist between switching, customer equity and purchase intentions and significance level is .000 . The study results with related with past studies (Chin and Chang 2008; Low and Johnston 2006). Regression analysis indicates that $\beta 1>0$ which shows that switching cost act as enhancer between the customer equity and purchase intentions $\beta 2>0, \beta 3>0$ ).

\section{Research contributions}

The current research seeks to find out the relationship of customer equity and its constructs which are value, brand and relationship equity toward the purchase intentions. The past researches conducted on the customer equity in other areas. In addition no earlier study has been conducted customer equity towards the brand preference purchase intentions by moderating role of switching cost. So, present research to conduct on customer decision making regarding customer equity toward the product and services in "Pakistan Airlines".

\section{Implication}

* The outcome of this research are significantly important for airlines as it will helps in understanding of having better relations with customers.

* The result of this research give motivation to companies and its marketer to make effective relationship with customers and companies can also utilize the tools to use in this study to test the role of customer equity and its drivers in getting the higher purchase intentions.

* Therefore the research only focuses on the airline industry. However result of this research can also be useful in other services provider industries or sectors by the help of literature of this research it has been cleared that increasing in customers brand preference and purchase intentions is much more profitable for marketing strategies.

* This research results also support the previous literature. Thus the finding provides an implication on branding strategies for airline to make up their sustained competitive advantage.

* In addition to analyses switching costs are enhancing recognized as a means for keeping customers in relationship.

\section{Future Research and Limitation}

Only a sample of the airlines customers in southern Punjab were studied in the present research, it may cause some limitation in generalizing the finding due to differentiation in low education, less traveling experience, low gender participations and feedback ratio. Second is, the future studies needs to prove that, customer equity and its drivers are valuable for businesses in different industries through strong argument. And third is, some other variables can enhance the customer's preference and purchase intentions such as social media, perceived value can affect the customers purchase intentions.

\section{References}

Biedenbach, G., Bengtsson, M., \& Marell, A. (2015). Brand equity, satisfaction, and switching costs: An examination of effects in the business-to-business setting. Marketing Intelligence \& Planning, 33(2), 164178

Chang, H. H., \& Liu, Y. M. (2009). The impact of brand equity on brand preference and purchase intentions in the service industries. The Service Industries Journal, 29(12), 1687-1706.

Chang, Y. H., \& Chen, F. Y. (2007). Relational benefits, switching barriers and loyalty: A study of airline customers in Taiwan. Journal of Air transport management, 13(2), 104-109.

Cobb-Walgren, C. J., Ruble, C. A., \& Donthu, N. (1995). Brand equity, brand preference, and purchase intent. Journal of advertising, 24(3), 25-40.

Emor, A. M. (2015). Analyzing brand equity on purchase intention through brand preference of samsung smartphone user in manado. Jurnal riset ekonomi, manajemen, bisnis dan akuntansi, 3(2).

Hanaysha, J. (2016). Building Brand Equity Through Customer Service: A Study on Restaurant Industry in Malaysia. Journal of Research in Business, Economics and Management, 5(5), 678-685.

Hyun, S. S. (2009). Creating a model of customer equity for chain restaurant brand formation. International Journal of Hospitality Management, 28(4), 529-539.

Jamal, A., \& Goode, M. M. (2001). Consumers and brands: a study of the impact of self-image congruence on brand preference and satisfaction. Marketing Intelligence \& Planning, 19(7), 482-492.

Kim, A. J. (2010). The effects of perceived social media marketing activities on customer equity and purchase intention: focus on luxury fashion brands. Unpublished master's thesis, Yonsei University.

Kim, A. J., \& Ko, E. (2010). Impacts of luxury fashion brand's social media marketing on customer relationship and purchase intention. Journal of Global Fashion Marketing, 1(3), 164-171. 
Kim, A. J., \& Ko, E. (2012). Do social media marketing activities enhance customer equity? An empirical study of luxury fashion brand. Journal of Business Research, 65(10), 1480-1486.

Kim, H. B., \& Kim, W. G. (2005). The relationship between brand equity and firms' performance in luxury hotels and chain restaurants. Tourism management, 26(4), 549-560.

Kim, K. H., Ko, E., Xu, B., \& Han, Y. (2012). Increasing customer equity of luxury fashion brands through nurturing consumer attitude. Journal of Business Research, 65(10), 1495-1499.

Kim, R. B. (2012). Determinants of brand equity for credence goods: Consumers' preference for country origin, perceived value and food safety. Agricultural Economics/Zemedelska Ekonomika, 58(7).

Lee, C. H., Ko, E., Tikkanen, H., Phan, M. C. T., Aiello, G., Donvito, R., \& Raithel, S. (2014). Marketing mix and customer equity of SPA brands: Cross-cultural perspectives. Journal of Business Research, 67(10), 2155-2163.

Lemon, K. N., Rust, R. T., \& Zeithaml, V. A. (2001). What drives customer equity. Marketing management, 10(1), 20.

Low, B., \& Johnston, W. J. (2006). Relationship equity and switching behavior in the adoption of new telecommunication services. Industrial Marketing Management, 35(6), 676-689.

Parasuraman, A., Zeithaml, V. A., \& Berry, L. L. (1988). Servqual: A multiple-item scale for measuring consumer perc. Journal of retailing, 64(1), 12.

Rust, R. T., Lemon, K. N., \& Zeithaml, V. A. (2004). Return on marketing: Using customer equity to focus marketing strategy. Journal of marketing, 68(1), 109-127.

Schivinski, B., \& Dabrowski, D. (2016). The effect of social media communication on consumer perceptions of brands. Journal of Marketing Communications, 22(2), 189-214.

Sharma, V., Singh, R., \& Patel, G. N. (2015). Measuring the effect of brand equity on the consumers' purchase intention. International Journal of Services Technology and Management, 21(1-3), 98-110.

Sun, Y., Garrett, T. C., \& Kim, K. H. (2016). Do Confucian principles enhance sustainable marketing and customer equity?. Journal of Business Research, 69(9), 3772-3779.

Vogel, V., Evanschitzky, H., \& Ramaseshan, B. (2008). Customer equity drivers and future sales. Journal of marketing, 72(6), 98-108.

Vukasović, T. (2016). An Empirical Investigation of Brand Equity: A Cross-Country Validation Analysis. Journal of Global Marketing, 29(5), 251-265.

Wang, K. Y., Hsu, L. C., \& Chih, W. H. (2014). Retaining customers after service failure recoveries: a contingency model. Managing Service Quality, 24(4), 318-338.

Wang, S. W. (2014). Do global airline alliances influence the passenger's purchase decision?. Journal of Air Transport Management, 37, 53-59.

Washburn, J. H., \& Plank, R. E. (2002). Measuring brand equity: An evaluation of a consumer-based brand equity scale. Journal of Marketing Theory and Practice, 10(1), 46-62.

Wood, L. (2000). Brands and brand equity: definition and management. Management decision, 38(9), 662-669.

Yoo, B., \& Donthu, N. (1997). Developing and validating a consumer-based overall brand equity scale for Americans and Koreans: an extension of Aaker's and Keller's coceptualizations. In AMA Summer Educators Conference, Chicago.

Yoo, B., \& Donthu, N. (2001). Developing and validating a multidimensional consumer-based brand equity scale. Journal of business research, 52(1), 1-14.

Yoo, B., Donthu, N., \& Lee, S. (2000). An examination of selected marketing mix elements and brand equity. Journal of the academy of marketing science, 28(2), 195-211.

Yoon, S., \& Oh, J. C. (2016). A cross - national validation of a new retail customer equity model. International Journal of Consumer Studies, 40(6), 652-664.

Zeithaml, V. A., Lemon, K. N., \& Rust, R. T. (2001). Driving customer equity: How customer lifetime value is reshaping corporate strategy. Simon and Schuster.

Zhang, S. S., van Doorn, J., \& Leeflang, P. S. (2014). Does the importance of value, brand and relationship equity for customer loyalty differ between Eastern and Western cultures?. International Business Review, 23(1), 284-292.

Vogel,V., Evanschitky, H., Ramaseshan, B: Customer Equity Driver and future Sales. American marketing association Vol. 72 98-108.

Chen, C,. Chang, Y.,(2008) Brand equity, brand preference, and purchase intentions- The moderating effect of switching costs. AIR TRANPORT MANAGEMENT 14(2008) 4-42

Yoshida, M., Gordon, B.(2012): Who is more influenced by customer equity drivers? A moderator analysis in a professional soccer context. Sport Management Review, 15(2012) 389-403.

Chang, H., Chen, S., (2008) The impact of online store environment cause on purchase intention. Online information review, Vol.32 (6) 818-841.

Hutchinson, J., Lai, F., Wang., (2009): Understanding the relationship of quality, value equity, satisfaction, and 
behavioral intentions among golf travelers. Tourism Management, 30(2009) 298-308.

Atilgan, E., Aksoy, S., Akinci, S., (2005): Determinent of the brand equity. Marketing Inteliligence \& Planning, Vol.23 (3) 237-248.

Yoshida, B., Gorden, M., (2012). Who is more influenced by customer equity drivers? A moderator analysis in a professional soccer context. Sport Management Review, 15(2012) 389-403. 